\title{
REVIEW : \\ KAJIAN LICHEN : MORFOLOGI, HABITAT DAN BIOINDIKATOR KUALITAS UDARA AMBIEN AKIBAT POLUSI KENDARAAN BERMOTOR
}

\author{
Efri Roziaty \\ Program Studi Pendidikan Biologi FKIP Universitas Muhammadiyah Surakarta \\ Email : er375@ums.ac.id
}

\begin{abstract}
Abstrak - artikel ini akan mengeksplorasi masalah lichen terkait dengan fungsinya sebagai bioindikator. Beberapa kriteria dikemukakan untuk bisa mengarahkan bahwa lichen memang layak untuk dijadikan bioindikator lingkungan khususnya mengenai kualitas udara. Polusi udara dapat mempengaruhi kondisi tumbuhan termasuk lichen secara fisiologis. Beberapa jenis lumut kerak dilaporkan dapat menjadi bioindikator yang peka terhadap pencemaran udara. Tulisan ini bertujuan untuk mengulas tentang lichen dari sisi morfologi, anatomi dan habitat serta keterkaitan lichen dengan polusi udara khususnya polusi yang disebabkan oleh pencemaran kendaraan bermotor. Berdasarkan atas substrat tempat tumbuhnya, lichen dibagi menjadi - Corticolous (lichen yang tumbuh di permukaan pohon), Follicolous (lichen yang tumbuh di permukaan daun), Saxicolous (lichen yang tumbuh di permukaan batu), Terricolous (lichen yang tumbuh di tanah), dan Musicolous (lichen yang tumbuh dengan lumut). Beberapa jenis lichen yang dapat dijadikan bioindikator pencemaran udara misalnya Parmelia, Hypogymnia dan Strigula selain itu masih ada jenis - jenis lichen lainnya yang terdeteksi sebagai indikator di daerah yang tercemar seperti Buelia punctata, Laurera bengaulensis, Lecanora paliida, D. picta, Trypethelium tropicum, Graphis liberta, dan Cryptothecia sp, Verrucaria sp., Heterodermia sp., Phaeographis sp., dan Heterodermia sp.
\end{abstract}

Kata kunci : lumut kerak, lichen, Corticolous, Follicolous, Saxicolous, Terricolous, Musicolous

\section{PENDAHULUAN}

\section{Lichen}

Di dunia ini ada sekitar 20.000 spesies alga. Sebagian besar berada di daerah tropis sebagai wilayah dengan tingkat keragaman organisme yang tinggi. Lichen merupakan tumbuhan yang mampu hidup di daerah ekstrem di permukaan bumi. Mereka dapat tumbuh di permukaan tanah, bebatuan, pepohonan bahkan permukaan permukaan benda buatan manusia.
Mereka ada di tempat yang jarang ada organisme yang mampu hidup di sana seperti puncah gunung, padang pasir, dan daerah kutub Di samping itu, lichen seringkali tumbuh di pohon dan semak - semak sebagai epifit, mereka tidak mengambil makanan dari organisme yang ditempelinya akan tetapimengambil makanan dari atmosfer. Lichen sangat beragam ukuran, warna dan bentuk. Mereka juga mampu berubah warna selama musim hujan ketika terbilas oleh 
air dan menghasilkan makanan (Kett, Dong, Andrachuck, \& Craig, 2005).

Lichen sekilas setipe dengan tumbuhan lumut. Tapi jika diperhatikan dengan seksama maka lichen merupakan suatu bentuk life form yang unik (khas). Lichen merupakan suatu komposisi organisme yaitu jamur dan alga atau cyanobakteri. Dua jenis organisme ini hidup saling berhubungan yang dinamakan simbiosis, alga menyediakan energi melalui proses fotosintesis dan jamur menyediakan tempat perlindungan bagi alga (Kett, Dong, Andrachuck, \& Craig, 2005).

Lichen merupakan suatu organisme hasil asosiasi simbiosis antara jamur dan algae dalam bentuk simbiosis mutualistik dan helotisme yang dapat membentuk kesatuan morfologi yang berbeda dengan spesies lain pada komponen - komponenya. Algae memiliki klorofil untuk melakukan fotosintesis sedangkan fungi mengambil air dan mineral lainnya dari lingkungan. Sedangkan helotisme maksudnya pada awalnya menguntungkan tapi selanjutnya fungi bersifat parasit pada alga dikarenakan hanya fungi yang memiliki alat perkembangbiakan berupa badan buah/thalus (Muzayyinah, 2005).

Berdasarkan fungsinya lichen memiliki nilai ekonomis diantaranya sebagai bahan obat - obatan (Parmelia sulcata) dan beberapa spesies Usnea untuk obat batuk, dan Cetraria islandica untuk obat diabetes, paru - paru dan katarak. Fungsi lainnya dari lichen adalah sebagai indikator, misal dari genus Cetraria sebagai indikator adanya marmer atau pualam (Muzayyinah, 2005).
Komponen jamur penyusun lichenes yang terbanyak adalah dari kelompok Ascomycetes (96\%), selanjutnya diikuti oleh Basidiomycetes, dan Deuteromycetes. Jamur berperan menyerap air dan mineral dari udara, proteksi dari perubahan fisik, suhu, dan intensitas sinar matahari tinggi. Dengan menyerap mineral dari udara sehingga lichen dapat digunakan untuk indikator biologi pencemaran udara (Aptroot, Diaz, Bárcenas-Peña, Cáceres, Fernando, \& Dal-Forno, 2014).

Untuk biomonitoring udara dengan indikator biologi lichen menggunakan beberapa metode yaitu perubahan komunitas dan perubahan fisiologi. Untuk perubahan komunitas memerlukan respon yang lama. Berbeda dengan perubahan fisiologi yang memerlukan respon yang cepat. Cara paling mudah melihat suatu daerah tercemar atau tidak dapat diketahui dari lichen didaerah tersebut. Sehingga indikator biologi lichen dapat diketahui dengan mudah oleh semua orang (Aptroot, Diaz, Bárcenas-Peña, Cáceres, Fernando, \& Dal-Forno, 2014).

Lichen dapat hidup bergantung pada kelembaban atmosfer: hujan, kabut \& embun untuk pertumbuhan. Karena lichen menyerap udara untuk kelangsungan kehidupannya tetapi udara yang mengandung air telah bercampur dengan polutan yang terlarut, sehingga polutan yang terlarut merusak jaringan pada lichen.

\section{Bioindikator}

Bioindikator atau biologi indikator atau Biological indicator merupakan organisme atau komunitas, yang reaksinya dianggap mampu 
mengevaluasi situasi atau kondisi yang memberitahukan adanya "sesuatu" dalam suatu ekosistem. Bioindikator mengidikasikan bahwa adanya benda benda asing seperti bahan - bahan fisika dan kimia yang mengalami perubahan jika ada ataupun tiada, jumlah, morfologi, fisiologi atau tingkah laku dimana spesies tersebut mengindikasikan adanya "sesuatu" di luar batas (Gerhardt, xxxx). Kebanyakan bioindikator merupakan spesies yang bereaksi terhadap pengaruh yang dilakukan oleh manusia terhadap lingkungan. Secara umum, definisi dari indikator biologis yaitu spesies yang mempengaruhi faktor - faktor biotik dan abiotik di suatu lingkungan, sebagai keterwakilan dari dampak perubahan lingkungan terhadap perubahan habitat, komunitas atau ekosistem atau "mengindikasikan" keragaman taksa atau keragaman hayati secara keseluruhan dalam suatu area (Savic, 1998).

Menurut (Savic, 1998), bioindikator berguna dalam tiga situasi berikut ini : 1) dimana faktor - faktor lingkungan tidak bisa diukur, misalnya, di siatuasi dimana faktor lingkungan di masa lalu direkonstruksi seperti perubahan iklim, pada studi tentang Palaeo - biomonitoring; 2) dimana faktor - faktor indikasi sulit diukur, misalnya, pestisida dan residunya atau racun kompleks yang mampu berinteraksi dan bereaksi secara kimia; dan 3) dimana faktor lingkungan mudah diukur tapi sulit diinterpretasikan, misalnya, observasi mengenai perubahan lingkungan yang memiliki pengaruh nyata kondisi ekologis (Martuti, 2013).

Perbedaan jenis bioindikator tersebut didasarkan atas perbedaan perpesktif (Gambar 2). Berdasarkan tujuan bioindikasi, bioindikator dapat dibedakan menjadi tiga macam : 1) indikator kesesuaian, 2) indikator diagnostik dan 3) indikator peringatan dini. Contoh indikator kesesuaian, populasi ikan yang diukur adalah populasi, komunitas atau ekosistem dan difokuskan pada isu keberlanjutan populasi atau komunitas sebagai suatu bagian yang utuh. Sedangkan, indikator diagnostik dan indikator peringatan dini diukur berdasarkan individu (pada tingkat biomarker). Indikator peringatan dini difokuskan pada sensitifitas respons terhadap perubahan lingkungan. akumulasi bioindikator (misalnya : pada kerang, lumut dan kerang) dibedakan berdasarkan efek toksik (Savic, 1998). 

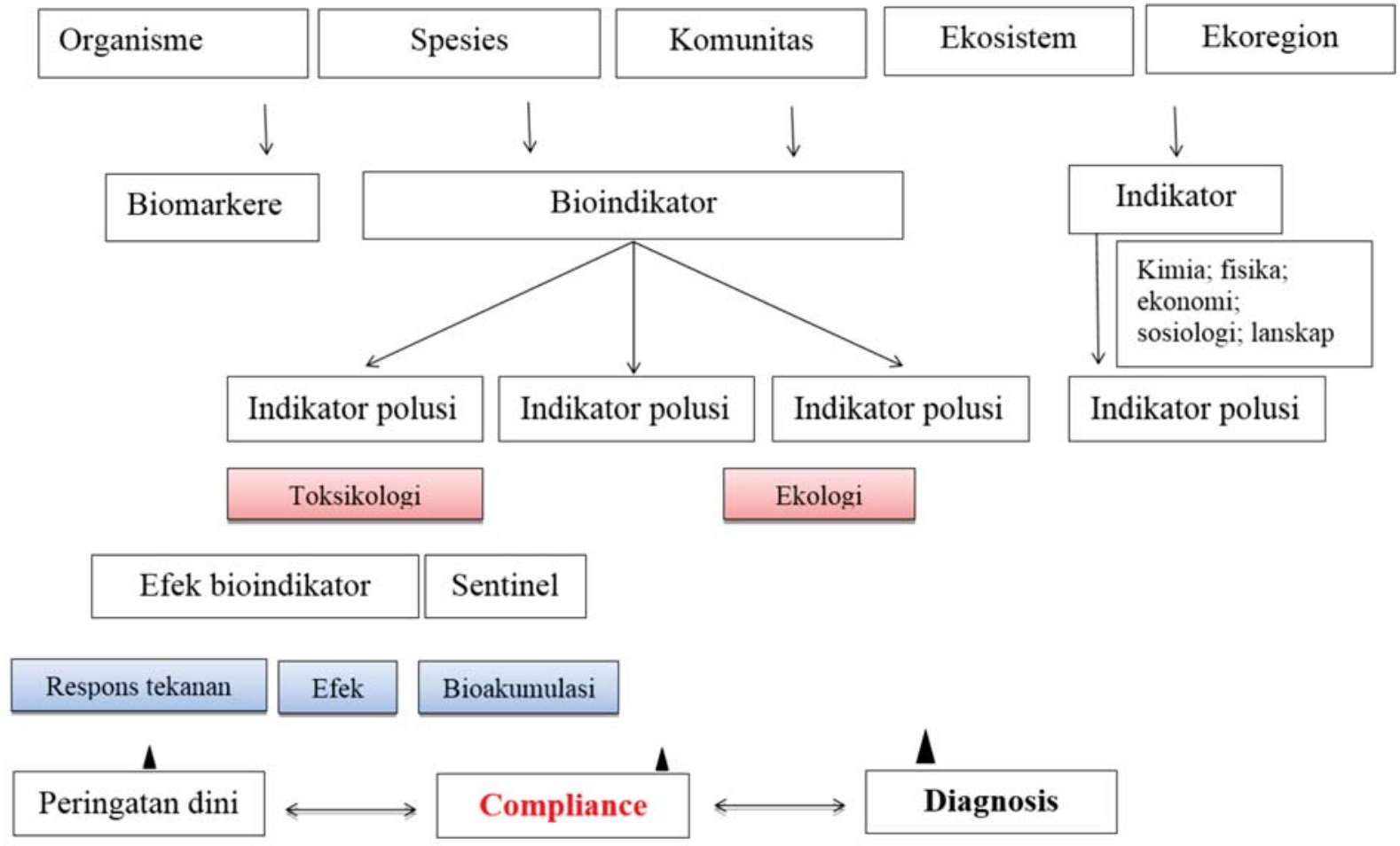

Gambar 2. Jenis - jenis bioindikator dalam konteks penggunaannya dalam biomonitoring (Gerhardt, xxxx)

Biondikator berdasarkan perbedaan aplikasi, dapat dibedakan menjadi tiga kategori yaitu : 1) indikator lingkungan : merupakan spesies atau kelompok spesies yang merespon gangguan lingkungan atau perubahan (contoh : organisme - organisme sentinel, detektor, eksploiter, akumulator, bioesay). Suatu sistem indikator lingkungan di susun berdasarkan tujuan indikator yaitu untuk mengdiagnosis kondisi lingkungan untuk membuat suatu kebijakan lingkungan. 2) indikator ekologi:inimerupakan suatu spesies yang diketahui sebagai organisme yang sensitif terhadap polusi, fragmentasi habitat atau tekanan lainnya. Respons indikator tersebut mewakili komunitas. Dan, 3) indikator biodiversitas. Kelimpahan spesies dari takson indikator digunakan untuk mengidikasikan kelimpahan suatu spesies di suatu lingkungan. istilahnya saat ini telah berkembang menjadi "parameter terukur biodiversitas", termasuk di dalamnya kelimpahan jenis, endemisme, parameter - parameter genetik, parameter spesifik - populasi dan parameter lanskap(Hardini, 2010).

3. Klasifikasi berdasarkan habitat dan morfologi lichen

Berdasarkan habitatnya, lichen dibedakan menjadi tiga kategori : 1) Saxicolous, merupakan lichen yang hidup di batu/cadas pada suhu dingin. Contoh : Acarospora ceruina, A. fuscata, Aspicillia corcota. 2) Corticulous, merupakan lichen yang hidup di pohon yang berperan sebagai epifit, kebanyakan di daerah tropis dan subtropis dengan kelembaban yang tinggi. Contoh : Usnea articulata, U. ceranita, U. hirta dan Artaria radiata. Dan, 3) Terriculous, merupakan 
lichen yang hidup pada tanah. Contoh : Cladonia ciliata, C. squamosa, C. uncialis, Peltigera canina, P. didactila, dan Leptogium britanicum (Muzayyinah, 2005).

Menurut klasifikasi morfologi lichen dibagi menjadi : 1) Thalus Crustose lichen - Lumut kerak yang memiliki thallus yang berukuran kecil,datar, tipis, dan selalu melekat pada permukaan batu, kulit pohon, atau tanah. Jenis ini susah untuk mencabutnya tanpa merusak substratnya. Permukaan thalus biasanyaterbagi menjadi areal - areal yang agak heksagonal yang disebut areole(Pratiwi, 2006). Contoh : Graphis scipta, Haematomma puniceum, Acarospora atau pleopsidium.



a

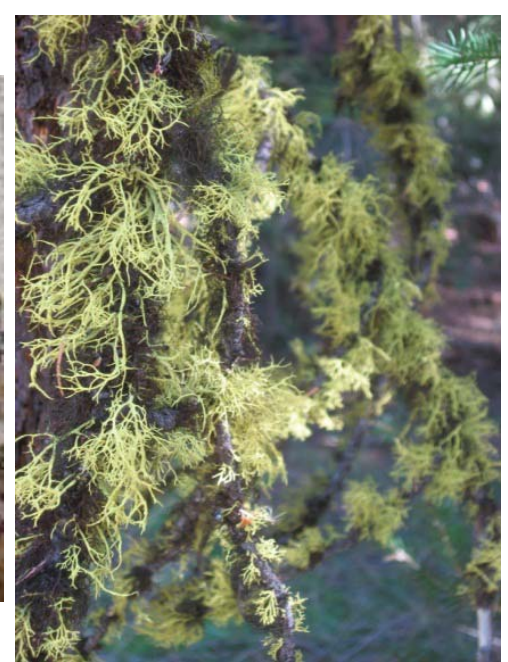

C

Gambar 1. Jenis - jenis lichen yang biasa di ditemui di Indonesia, jenis ini berdasarkan karakteristik morfologi lichen. a) Crustose; b) Foliose; dan c) Fruticose (Pratiwi, 2006).

2) Thalus Foliose lichen - Lichen foliose memiliki struktur seperti daun yang tersusun oleh lobus-lobus. Lichen in relatif lebih longgar melekat pada substratnya. Lumut kerak ini melekat pada batu, ranting dengan rhizin. Rhizines ini juga berfungsi sebagai alat untuk mengabsorbsi makanan. Contoh : Xantoria, Physicia, Peltigera, Parmelia. Fruticose lichen. Thalusnya berupa semak dan memiliki banyak cabang dengan bentuk seperti pita. Thallus tumbuh tegak atau menggantung pada batu, daun-daunan atau cabang pohon. Contoh : Usnea, Ramalina dan
Cladonia - Squamulose lichen. Lichen ini memiliki lobus-lobus seperti sisik, lobus ini disebut squamulus yang biasanya berukuran kecil dan saling bertindih dan sering memiliki struktur tubuh buah yang disebut podetia(Gambar 1).

Dari keempat kriteria bentuk lichen terdapat tiga lichen sebagai indikator pencemaran udara yaitu Fruticose, Foliose, dan Crustose. Fruticose menjadi jenis lichen yang paling sensitif terhadap pencemaran udara kemudian Foliose dan jenis Crutosie masih sedikit mentoleransi pencemaran udara. Sehingga jika suatu daerah tidak terdapat Fruticose maka 
daerah tersebut udara dapat dikatakan tercemar. Perubahan jenis lichen juga terjadi sesuai dengan pencemaran yang terjadi di daerah tersebut. Kepekaan lichen berada dalam berbagai radius dari sumber pencemar (Pratiwi, 2006).

Untuk mengidentifikasi lichen tercemar polutan perlu dilakukan identifikasi pada tingkat spesies, morfologi, taksonomi, dan anatomi. Dengan melakukan beberapa identifikasi tersebut dapat mengetahui polutan yang terdapat didaerah tersebut. Lichen menjadi sangat peka pada polutan karena lichen tidak memiliki lilin \& kutikula untuk melindungi sel-sel (struktur dalam). Sehingga polutan mudah terserap oleh klorofil lichen dan merusak jaringan lichen (Pratiwi, 2006).

\section{Anatomi lichen}

Lichen merupakan simbiosis antara dua jenis organisme. Organisme tersebut yaitu fungi (mikrobion) dan alga (cyanobacteria, protobion). Protobion menghasilkan makanan dari fungsi dari proses fotosintesis dan fungi juga melindungi alga dengan menyisakan air dan menyediakan nutrisi mineral (Sujetoviene, 2010). Simbiosis yang terjadi mengakibatkan kedua komponen tersebut saling tergantung satu sama lain. Lumut kerak dapat mengabsorbsi air dari hujan, aliran permukaan dan embun(GC, Catalano I, \& A, 2011) (Pratiwi, 2006).

Secara anatomi, jaringan thalus tersusun atas beberapa lapisan diantaranya : 1) lapisan yang paling atas disebut sebagai lapisan hifa fungi. Lapisan ini tidak memiliki ruang antar sel jika ada biasanya diisi dengan gelatin. Pada beberapa jenis lumut kerak yang bergelatin, kulit atas juga kekurangan satu atau beberapa sel tipis. Namun, permukaan tersebut tertutupi oleh epidermis. 2) lapisan alga, berada di bawah lapisan korteks atas yang terdiri atas lapisan gonidial. Lapisan ini merupakan jalinan hifa fungi yang bercampur dengan alga. Berdasarkan penyebaran lapisan alga pada thalusnya, lumut kerak telah diklasifikasi menjadi dua kategori yaitu homoiomerus dan heteromerous. Homoiomerus, sel alga tersebar merata pada jaringan longgar hifa fungi sedangkan pada heteromerous sel - sel alga terbatas pada lapisan atas thalus(Pratiwi, 2006)(GC, Catalano I, \& A, 2011). 3) Medulla, merupakan lapisan yang terdiri atas hifa longgar. Lapisan ini akan memberikan kekuatan dan penghubung antara lapisan bawah dan atas atau bagian luar dan dalam thalus. Lapisan ini menyerupai lapisan parenkim bunga karang seperti jaringan daun. Pembagian atau pemisahan antara lapisan alga dan lapisan medulla tidak selalu terjadi secara sempurna. Pada lapisan ini hanya sedikit terdapat sel sel alga, pada uumumnya lapisan ini relatif tebal dan tidak berwarna atau transparan; 4) Korteks bawah, lapisan korteks bawah ini menyerupai lapisan korteks atas. Di lapisan ini terbentuk rhizoid yang berkembang masuk ke substrat. Jika tidak ada rhizoid, maka fungsinya akan digantikan dengan hifa hifa fungi yang merupakan perpanjangan hifa dari lapisan medulla (Pratiwi, 2006).

Alga yang menyusun tubuh lichen disebut gonidium, bisa berbentuk uniseluler atau multiseluluer. Kebanyakan gonidium biasanya berupa ganggang biru (cyanophyceae) antara lain Chroococcus dan Nostoc, atau bahkan kadang - kadang ganggang hijau 
(Chlorophyceae) misal Cystococcus dan Trentepohlia. Kebanyakan fungi yang menyusun lichen termasuk ke dalam Ascomycetesterutama Discomycotales, hanya kadang - kadang Pyrenomycetales. Kebanyakan fungi tertentu bersimbiosis dengan ganggang tertentu pula. Lichen termasuk tumbuhan alami yang sulit untuk didomestikasi sekalipun sudah disediakan medium yang tepat bagi lichen. Akan tetapi jika masing - masing dibedakan, masih bisa tumbuh dalam media buatan (Tjitrosoepomo, 1998).

Menurut (Tjitrosoepomo, 1998) dapat dipandang bahwa hubungan antara ganggang dengan jamur sebagai suatu hubungan yang helotisme. Keuntungan timbal balik yang didapat hanya sementara saja yaitu ketika di bagian permulaan saja, tapi pada akhirnya ganggang akan dimanfaatkan oleh fungi (seperti hubungan antara majikan dengan pembantunya, helot) sehingga diistilahkan sebagai helotisme.

\section{Habitat dan penyebaran lichen}

Lichen atau umut kerak tumbuh tidak hanya di pepohonan akan tepai juga di atas permukaan tanah, terutama di daerah - daerah ekstrem misalnya di daerah tundra. Lokasi tumbuhnya lichen tidak dipengaruhi oleh ketinggian dari permukaan laut. Tumbuhan ini termasuk tumbuhan perintis yang ikut berperan dalam pembentukan tanah. Tempat tumbuh lichen tidak terikat tempat, bisa saja di bebatuan atau pada cadas di bebatuan di atas permukaan laut, atau di gunung - gunung yang tinggi. Dengan karakter inilah, lichen dikatakan memiliki sifat endolitik (Tjitrosoepomo, 1998).

Lichen tidak membutuhkan syarat - syarat hidup yang tinggi, tahan terhadap kondisi kekurangan air dalam jangka waktu yang lama, tahan terhadap panas terik. Jika cuaca pana, lichen akan berubah warna seperti kekeringan, tetapi tidak mati. Jika disirami air maka lichen akan hidup kembali. Pertumbuhan thalus sangat lambat, dalam satu tahun biasanya kurang dari $1 \mathrm{~cm}$. tubuh buah baru terbentuk setelah mengadakan pertumbuhan vegetatif bertahun - tahun (Tjitrosoepomo, 1998).

Hubungan simbiosis tersebut memungkinkan bagi lichen untuk hidup di berbagai tempat/habitat dan kondisi cuaca di seluruh dunia bahkan di lingkungan yang ekstrim. Di wilayah yang kodisi lingkungan seragam masing - masing substrat cenderung lichen yang tumbuh juga relatif seragam. Mereka tumbuh di lingkungan dengan kondisi iklim yang berbeda dan dengan substrat yang berbeda. Mereka mampu dengan cepat menyerap dan menyiapkan air dari banyak sumber maka memungkinkan bagi lichen untuk hidup di lingkungan yang "keras" seperti gurun dan kutub, dan terpapar pada suatu permukaan I yang datar, dinding, atap, dahan/ranting pohon dan material buatan manusia lainyya seperti gelas, logam dan lain sebagainya. Lichen ini merupakan vegetasi perintis bagi habitat terestrial dari kutub utara hingga di banyak gurun (Gambar 2) (Bhat, Dudani, \& Subhash, xxxx) 


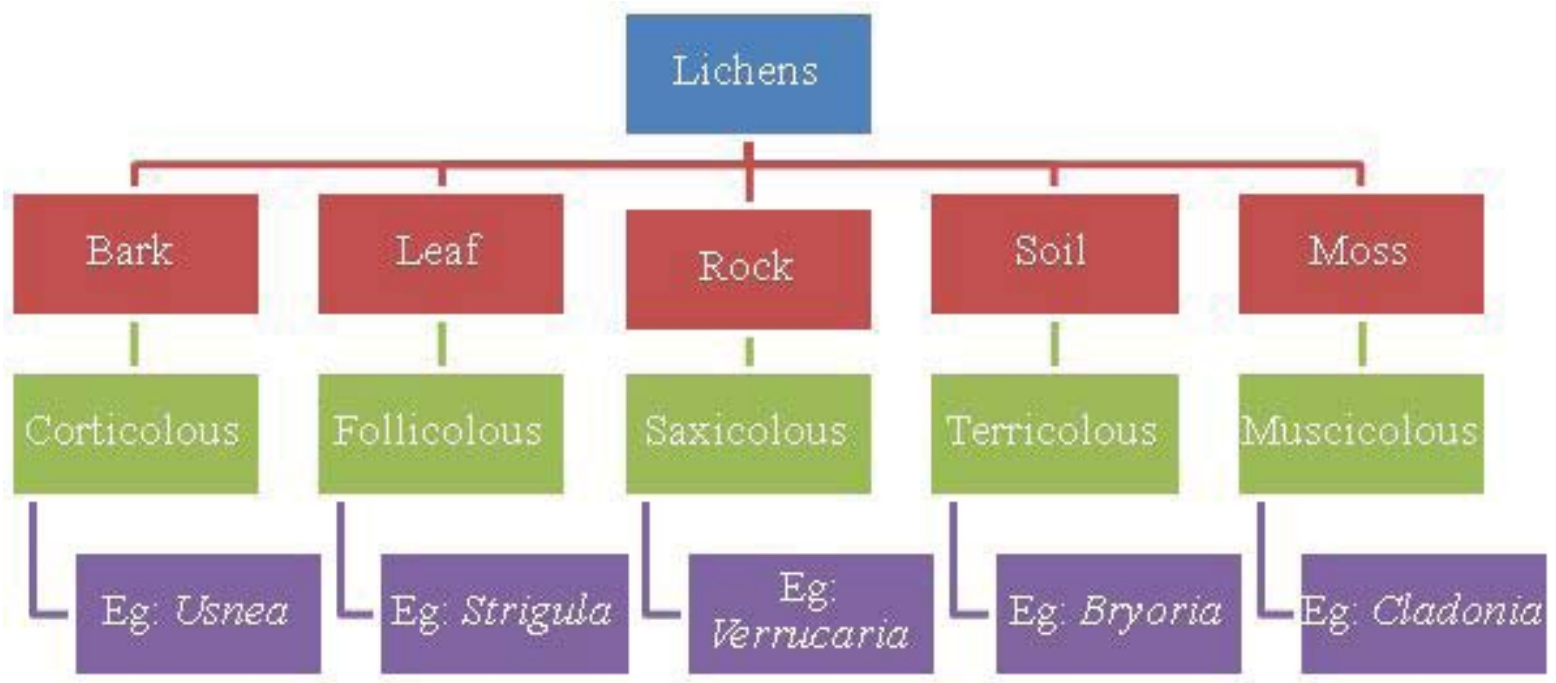

Gambar 2. Perbedaan habitat lichen. lichen yang tumbuh di berbagai habitat di dunia. Sumber: (Bhat, Dudani, \& Subhash, xxxx)

Berdasarkan atas substrat tempat tumbuhnya, lichen dibagi menjadi Corticolous (lichen yang tumbuh di permukaan pohon), Follicolous (lichen yang tumbuh di permukaan daun), Saxicolous (lichen yang tumbuh di permukaan batu), Terricolous (lichen yang tumbuh di tanah), dan Musicolous (lichen yang tumbuh dengan lumut) (Bhat, Dudani, \& Subhash, xxxx).

Komunitas Corticolous : Lichen berkembang di permukaan pohon dan ter frutiri atas spesies fruticose dan foliose (Gambar 3). Yang termasuk di dalamnya adalah spesies Evernia, Parmelia dan Usnea. Pertumbuhan lichen di permukaan pohon tergantung pada kestabilan pohon tersebut, tekstur, pHdan ketersediaan air. Permukaan yang kasar termasuk lichen Parmelioid and Physioid dengan anggota Buellia, Lecanoraceae, Lecideaceae dan Pertusariaceae. Permukaan yang kasar memerangkap spora-nya atau diaspora vegetatif dan menyediakan kelembaban dalam waktu yang lama (Bhat, Dudani, \& Subhash, xxxx).

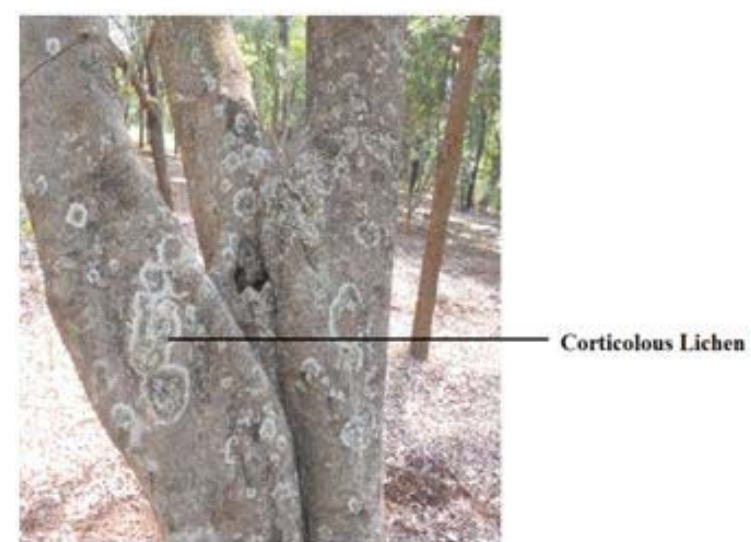

Gambar 3. Corticulous lichen(Bhat, Dudani, \& Subhash, xxxx)

Komunitas Follicolous : Spesies lichen yang tumbuh di permukaan daun disebut dengan lichen fullicolous, yang termasuk di dalamnyaseperti Calicium, Cyphelium and Strigula. Biasanya lichen ini menyukai daun yang tterkena sinar matahari, licin, berwarna hijau sepanjang tahun yang terletak di bagian luar kanopi pohon, di bawah tegakan, di batas cahaya dan di dekat pemukaan badan air(Bhat, Dudani, \& Subhash, xxxx). 


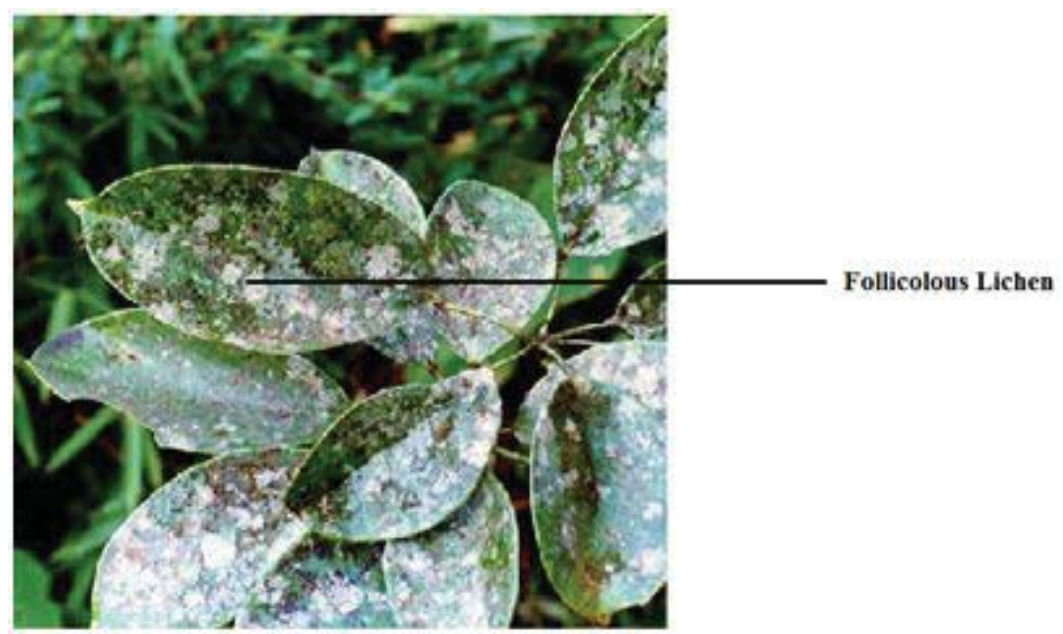

Sumber (http://www.tnenvis.nic.in/Lichens/Field\%20study.htm) Gambar 4. Lichen fullicolous.

Komunitas Saxicolous : komunitas lichen yang berkembang di substrata bebatuan, jenis ini sangat tergantung tipe batu. Tipe batu dan $\mathrm{pH}$ merupakan faktor penting yang bertanggung jawab atas pembentukan koloni komunitas lichen jenis ini. spesies yang termasuk di dalamnya seperti Caloplecta, Aspicilia tumbuh di atas permukaan batu akik. Spesies Verrucaria dapat di temukan di daerah bebatuan di sumur. Lepraria, komunitas Cystocoleus yang tumbuh di permukaan batu silika(Bungartz, III, \& Ryan, 2004).



Gambar 5. Lichen Saxicolous (Bhat, Dudani, \& Subhash, xxxx) 
Bioeksperimen

Volume 2 No. 1, (Maret 2016)

ISSN 2460-1365

Komunitas Terricolous : Lichen di komunitas ini tumbuh di permukaan halaman atau tanah dan bahkan seringkali membentuk komponen yang dominan pada vegetasi lahan biasa di lingkungan ekstrim (Fryday, 2001). Komunitas terricolous semakin tereduksi dari waktu ke waktu akibat kegiatan manusia.

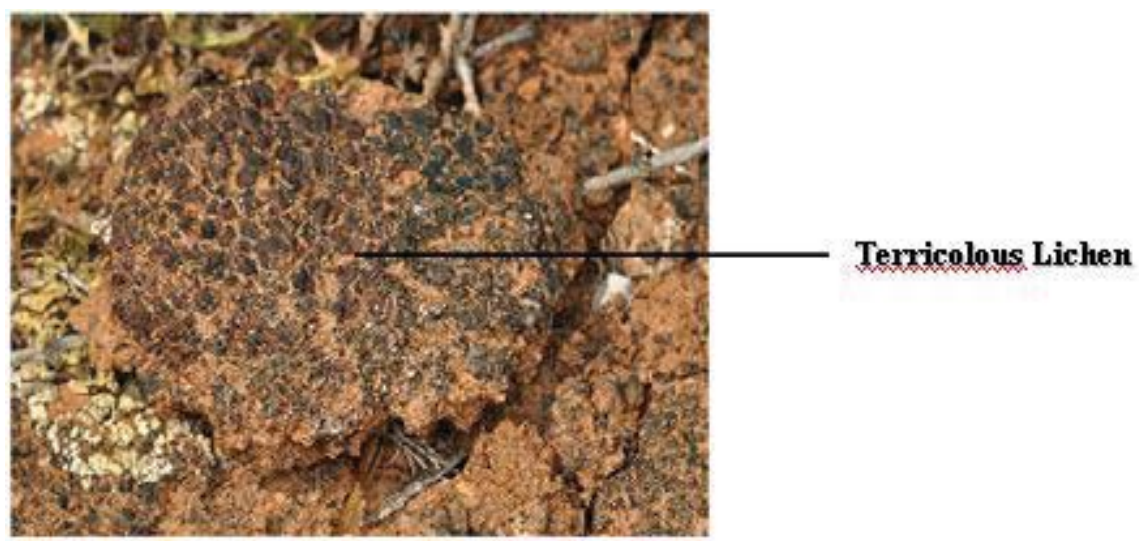

Gambar 6. Lichen Terricolous

(Source: www.waynesword.palomar.edu)

Komunitas Muscicolous : Lichen jenis ini tumbuh di lumut (Gambar 7). Beberapa spesies jenis Cladonia, Peltigera tumbuh pada tumbuhan lumut. Mereka menyukai lumut - lumut alami yang kasar yang efisien dalam propagula lichen. lumut menyediakan air yang cukup dan relung iklim mikro yang baik bagi lichen untuk tumbuh (Bhat, Dudani, \& Subhash, xxxx)(Diedrich \& Lawrey, 2007).



Gambar 7. Lichen Muscicolous

(Source: www.google images/broad-horizon-photos.co.uk/lichens) 


\section{Lumut kerak sebagai bioindikator kualitas udara}

Lichen diketahui merupakan tumbuhan yang peka terhap pencemaran udara. Jika kulitas udara di suatu lingkungan telah menurun maka beberapa jenis lichen akan menghilang seiring dengan meningkatnya konsentrasi polusi di udara. Lichen dapat mengindikasikan atau mencirikan polusi udara khususnya yang berasal dari emisi kendaraan bermotor. Dengan adanya pencemar di udara akan menyebabkan terhambatnya pertumbuhan lichen. Selain itu, terjadi juga penurunan jumlah jenis (genus) lichen yang dapat dijadikan indikator pencemaran udara.

Beberapa jenis lichen yang dapat dijadikan bioindikator pencemaran udara misalnya Parmelia, Hypogymnia dan Strigula(Pratiwi, 2006). Berdasarkan studi kasus yang dilakukan di Thailand (Conti \& Cecchetti, 2001), mengindikasikan bahwa ada 7 jenis lichen dari sekitar 20 pohon yang dijadikan sampel untuk meneliti jenis lichen yang ditemukan di daerah yang terpolusi yaitu Buelia punctata, Laurera bengaulensis, Lecanora paliida, D. picta, Trypethelium tropicum, Graphis liberta, dan Cryptothecia sp.

Padalokasi pengamatan dikawasan industri Pulo Gadung ditemukan 3 jenis lumut kerak (Phaeographis sp., Strigula sp. dan D. cf picta). Pada arboretum Cibubur ditemukan 6 jenis lumut kerak (Strigula sp., Verrucaria sp., Graphidaceae, Heterodermia sp dan $P$. cf austrosinensis). Pada tegakan mahoni Cikabayan ditemukan 10 jenis lumut kerak (Graphidaceae, Strigula sp. Dan Verrucaria sp., Phaeographis sp., Parmelia sp. dan Heterodermia sp.) (Pratiwi, 2006).

\section{SIMPULAN DAN SARAN}

Berdasarkan atas substrat tempat tumbuhnya, lichen dibagi menjadi Corticolous (lichen yang tumbuh di permukaan pohon), Follicolous (lichen yang tumbuh di permukaan daun), Saxicolous (lichen yang tumbuh di permukaan batu), Terricolous (lichen yang tumbuh di tanah), dan Musicolous (lichen yang tumbuh dengan lumut). Beberapa jenis lichen yang dapat dijadikan bioindikator pencemaran udara misalnya Parmelia, Hypogymnia dan Strigula selain itu masih ada jenis - jenis lichen lainnya yang terdeteksi sebagai indikator di daerah yang tercemar seperti Buelia punctata, Laurera bengaulensis, Lecanora paliida, D. picta, Trypethelium tropicum, Graphis liberta, dan Cryptothecia sp, Verrucaria sp., Heterodermia sp., Phaeographis sp., dan Heterodermia sp.

Beberapa saran yang mungkin bisa dijadikan acuan untuk penelitian-penelitian mengenai lichen selanjutnya adalah meneliti tidak hanya morfologi fisiknya akan tetapii kandungan polutan apa saja yang berada di dalam tubuh lichen yang berada di daerah tercemar, selain itu yang perlu diperhatikan juga adalah lingkungan tempat tumbuh lichen yang secara khusus harus dibedakan mengenai jenis substrat, umur lichen dan iklim mikro yang mana ketiga hal ini masih agak sulit dilakukan karena masing masing memiliki kendala teknis tersendiri. Selain itu, penelitian mengenai lichen ini perlu terus dilakukan hingga kajian - kajian tentang lichen dengan memperluas wilayah penelitian sehingga akan di dapat faktor lingkungan yang jelas - jelas berbeda.

\section{DAFTAR PUSTAKA}

Aptroot, A., Diaz, J. A., Bárcenas-Peña, A., Cáceres, M. E., Fernando, L., \& DalForno, M. (2014). Rapid assessment 
of the diversity of "vehiculicolous" lichens on a thirty year old Ford Bronco Truck in Central Puerto Rico. Fungi, 22-27.

Bhat, S. P., Dudani, S. N., \& Subhash, M. (xxxx). Shilapuspa - Lichen: General Characteristics. India: Indian Institute of Science, Bangalore.

Bungartz, F., III, T. N., \& Ryan, B. (2004). Morphology and Anatomy of Chasmolitic Versus Epilitic Growth : a Taxonomic Revision of Inconspicuous Saxilous Buella species From The Sonoran Desert Region Generally Ascribed to The "Buella punctata" Group. Canadian Journal of Botany, 540-562.

Conti, M., \& Cecchetti, G. (2001). Biological Monitoring:lichens asbioindicators of air pollution assessment - a review. Environmental Pollution, 471-492.

Diedrich, P., \& Lawrey, J. D. (2007). New lichenicolous, muscicolous corticolous and lignicolous of Burgoa s. 1. and Marchandiomyces s. 1. (anamorphic Basidiomycota), a new genus for Omphalina foliacea, and a catalogue and a key to the non-lichenized, bulbilliferous basidiomycetes. mycol. Progress, 6180.

Fryday, A. M. (2001). Phytosociology of terricolous lichen vegetation in the Cairngorm Mountains, Scotland. Lichenologist, 331-351.

GC, A., Catalano I, M., \& A, M. (2011). Monitoring Epiphytic Lichen Biodiversity to Detect Environmental Quality and Air Pollution the Case Study of Roccamonfina Park (Campania
Region - Italy). In Air Pollution New Development (pp. 227-244). Italiy : Intech .

Gerhardt, A. (xxxx). Bioindicator Species and Their Use in Biomonitoring . Germany : LimCo International.

Hardini, Y. (2010). Keanekaragaman Lichen di Denpasar Sebagai Bioindikator Pencemaran Udra. Seminar Nasionl Biologi Fakultas Biologi UGM (pp. 790-793). Jogjakarta: UGM Press.

Kett, A., Dong, S., Andrachuck, H., \& Craig, B. (2005). Learning with Lichens : Using Epiphytic Lichens as Bioindicators of Air Pollution. United States: Brook University.

Martuti, N. K. (2013). Peranan Tanaman Terhadap Pencemaran Udara di Jalan Protokol Kota Semarang. Biosantifika - Berkala Ilmiah Biologi, 36-42.

Muzayyinah. (2005). Keanekaragaman Tumbuhan Tak Berpembuluh. Solo, Jawa Tengah, Indonesia: Lembaga Pengembangan Pendidikan (LPP) UNS.

Pratiwi, M. E. (2006). Kajian Lumut Kerak Sebagai Bioindikator Kualitas Udara Studi Kasus : Kawasan Industri Pulo Gadung, Arboretum Cibubur dan Tegakan Mahoni Cikabayan. Bogor: IPB Press.

Savic, S. (1998). Epiphytic Lichens as Bioindicators of Air Pollution in the Area of Belgrade. IAL 3 (pp. 331334). Belgrade: Verlag Alexander Just .

Sujetoviene, G. (2010). Road traffic pollution effects on epiphytic lichens. Ekologija, 64-71. 
Bioeksperimen

ISSN 2460-1365

Tjitrosoepomo, G. (1998). Taksonomi Tumbuhan-Schizophyta, Thallophyta,
Bryophya, Pterydophyta. Yogjakarta: Gajah Mada University Press. 